\title{
LAS COFRADÍAS EN EL REINO DE VALENCIA. ANÁLISIS Y CLAVES INTERPRETATIVAS ${ }^{1}$
}

\author{
MANUEl BENÍTEZ BOLORINOS \\ Universidad de Alicante
}

Resumen: Entre los años 1329 y 1458 , el reino de Valencia asistió al desarrollo de un movimiento asociativo, paralelo a otras regiones europeas, que dio lugar a la aparición de un buen número de corporaciones divididas en dos grandes grupos: cofradías religiosas y cofradías de oficio. Sus objetivos eran cubrir una serie de necesidades espirituales y benéficas, pero también servir de representación a los oficios artesanos, buscando así una mayor influencia en el mundo urbano a través de la ostentación de una serie de símbolos, que permitieron un alto grado de exhibición social.

Palabras clave: Cofradía; Oficio; Reino de Valencia; Artesano; Gremio; Ordenanzas.

\begin{abstract}
Between 1329 and 1458 the kingdom of Valencia witnessed a development of an assocaitive movement parallel to other European regions, which gave rise to the appearence of a great number of associations divided in two main groups: religious and trade brotherhoods. Their objectives were to cover a series of spiritual and charity needs, and also to serve as a representation for the traditional handicrafts, looking for a great influence on the urban world by means of a series of symbols, which permited a high grade of social exhibition.
\end{abstract}

Keywords: Brotherhood; Trade; Kkingdom of Valencia; Craftman; Guild; Bylaw

\section{SUMARIO}

1.- La construcción de un reino.- 2. La consolidación del fenómeno asociativo.- 3. Cofradías, gremios, hermandades: el espinoso asunto de la terminología.- 4. Una propuesta de sistematización. 4.1. Religión, solidaridad y jerarquía como elementos de cohesión. 4.2. Representación externa. Exhibición social.- 5. Conclusiones. Un fenómeno en permanente transformación.

${ }^{1}$ El presente trabajo es una ampliación de la memoria de licenciatura publicada por la 1458). Alicante 1998 . Se trat por tanto de un artículo que permite profundizar y valorar de una forma más amplia la publicación anterior, centrada en el estudio de las ordenanzas de las una róna más anplia la publicación anterior, centrada en el estudio de las ordenanzas de las cofradias en dicho periodo. Al mismo tiempo, ambos trabajos se complementan, ya que esta nueva aproximación al tema de las cofradías debe entenderse como una extensión de lo publicado anteriormente. 


\section{LA CONSTRUCCIÓN DE UN REINO}

La articulación de las cofradías en el contexto del mundo artesano es un reflejo de la complejidad existente en la ciudad medieval. La variedad de intereses y objetivos que se entretejen en la urbe, la multiplicidad de fuerzas que se encuentran en tal escenario, las respuestas coyunturales a acontecimientos concretos o el desarrollo de estructuras más permanentes no deben de ser entendidos como simples obstáculos para su interpretación, sino como parte integrante de la naturaleza de estas asociaciones, ya que las cofradías (sus aspiraciones, intereses y prácticas) son una respuesta a tales "obstáculos", vividos por los cofrades de primera mano.

El desarrollo de estas agrupaciones manifiesta elementos comunes en buena parte de la Europa cristiana. Desde Cracovia a los reinos peninsulares, pasando por la Hansa, los Países Bajos, Francia o Italia, la devoción religiosa a un símbolo concreto (un santo, la virgen o Cristo), la asistencia entre los hermanos cofrades, la búsqueda de una cohesión interna y solidaria, la rivalidad entre las cofradías o las relaciones de conflicto y colaboración con autoridades superiores, son referentes habituales en la bibliografía de aquellos investigadores que han tratado de abordar este tema. Aún así, en cada región aparecen singularidades que complican una posible sistematización, y que al mismo tiempo la enriquecen.

En el caso concreto del reino de Valencia, nos encontramos con una serie de características -un marco general- que permiten encuadrar una gran variedad de fenómenos, entre ellos la explosión confraternal vivida en dicho territorio a partir de 1329 .

Tomando como punto de partida esta fecha, el reino se entiende como un espacio de conquista y repoblación reciente, al igual que la mayoría de territorios peninsulares. No hace ni un siglo de su creación (1238, toma de Valencia) y casi veinticinco años de su conformación más o menos definitiva (Tratado de Torrellas, 1304). Este cuadro general aporta una serie de connotaciones que regirán, o al menos orientarán, algunos de los contenidos del mundo urbano:

-Territorio de reciente incorporación a la Corona.

-Escasez de nuevos pobladores cristianos.

-Necesidad de ofrecer un dinamismo económico que estructure el reino. incorporadas.

-Conformación de un orden político y social en las ciudades

-Y, por último, apropiación ideológico-religiosa de un solar que ha pertenecido a Sharq al-Andalus y en la que pervive un importante contingente mudéjar.

Bajo estas coordenadas se desarrollaron una serie de impulsos, no exentos de contradicciones y rivalidades internas, que sirvieron de marco general para el mundo urbano valenciano, es decir, un ámbito complejo y multiforme donde se establecieron los movimientos confraternales. 
Estamos, por tanto, ante una serie de hitos iniciales que deben de tenerse en cuenta a la hora de abordar el estudio de las cofradías del reino. En primer lugar, se trata de un territorio que pasó a manos de la Corona de Aragón tras un proceso de conquista y repoblación. Cualquier elemento introducido implicó una novedad, una incógnita en dicho espacio, aunque viniera precedido por un utillaje mental y una experiencia previa por parte de los conquistadores y de los nuevos pobladores.

Las características fundamentales de este periodo fueron la forma como se realizó la conquista, la presencia de un sustrato poblacional previo, y el modo de asentamiento de los repobladores.

En este sentido, la sociedad musulmana precedente mostraba una serie de características que condicionaron el esfuerzo bélico de los cristianos. Desde el punto de vista político destacó su manifiesta descomposición. Desde el socioeconómico, las ciudades eran los centros de poder y permitían el control de todo el territorio adyacente. Por ese motivo, la estrategia seguida por Jaime I no se realizó mediante "la incorporación sucesiva de las diversas líneas fortificadas", sino a través el asalto y rendición de las ciudades ${ }^{2}$.

Estamos en el mismo contexto temporal en el que la mayor parte de la Europa cristiana comenzaba a recuperar su dinamismo urbano. Con la ciudad como marco de desarrollo económico, de conflictividad política, de representación social, de promoción y marginalidad, aparecieron los movimientos corporativos, ya fuera para cubrir una serie de necesidades económicas, espirituales o humanitarias, y por lo tanto también políticas. Así, entre 1150 y 1250 aparecieron en Europa occidental una multitud de documentos poniendo por escrito las costumbres locales: el código jurídico, el régimen fiscal, los reglamentos internos de la vida en común y de la vida económica ${ }^{3}$.

En el reino de Valencia, sin embargo, la situación todavía se encontraba en una fase preliminar de instalación del contingente poblacional que debía propiciar ese resurgir de lo urbano.

Para asentar sus propias bases demográficas, los conquistadores utilizaron el sistema del repartimiento, tanto en la propiedad urbana como en la rural, resultando beneficiados, inicialmente, aquellos que habían colaborado en la campaña militar. El sistema se extendió a continuación a todos los que

\footnotetext{
${ }^{2} \mathrm{P}$. LÓPEZ Elum, La conquista y repoblación valenciana durante el reinado de Jaime I, Valencia, 1995, p. 49.

${ }^{3}$ Ampliando a otros territorios de la Europa cristiana, en el Languedoc pasaron de un escaso número de solidaridades vecinales a un desarrollo completo de instituciones municipales bajo la fórmula del "consulat". La práctica del escrito resultó fundamental para estas nuevas "universités". M. BOURIN. Les solidarités villageoises et l'écrit: La formalisation des années $1150-1250$. L exemple languedocien, en Cofradias, gremios y solidaridades en la Europa Medieval " Actas de la XIX Semana de Estudios Medievales de Estella. 20-24 de julio de 1992"). Estella 1992, pp.31-34. En el caso portugués el movimiento confraternal eclosionó en el siglo XII con la reforma gregoriana y con las predicaciones de dominicos y franciscanos en el siglo XII con la reforma gregoriana y con las predicaciones de dominicos y franciscanos en las ciudades. Los años de peste y guerra hicieron necesarias nuevas estrategias de ayuda y unión entre los hombres. La huida al campo llevó a la pérdida de raíces y al crecimiento de las cofradías como familias artificiales. M.H. DA CRUZ COELHO, As confrarias medievais portuguesas: espaços de solidaridades na vida $e$ na morte, en Cofradías, gremios y solidaridades, pp. 156-157
} 
quisieron acudir al nuevo reino. Se les ofrecía una casa y tierra de secano o regadío, con una extensión que dependía de su categoría social, a cambio de fijar la residencia y defender el reino ${ }^{4}$.

Es evidente que esta acción repobladora suponía una continuación de la acción conquistadora. Para las autoridades de la Corona resultaba mucho más sencillo controlar un territorio cuya población era cristiana que si era exclusivamente musulmana. Así que, progresivamente, y en un proceso no exento de altibajos, la sociedad cristiana fue ganando terreno a la mudéjar 5 . En ambas comunidades se observa la implantación del modelo de sociedad que aportaban los conquistadores: el feudalismo. Los primeros años de presencia cristina se caracterizaron por la tolerancia hacia los moros como consecuencia de los pactos de rendición (Acuerdo de Alcaraz, 1243). La presencia cristiana era fundamentalmente militar, aunque iniciándose un proceso de atracción de repobladores cristianos para garantizar el control de las ciudades y del campo, evitando su vez el desplome económico del país. De esta manera se implantaba el nuevo modelo de sociedad feudal, sometida a un señor ${ }^{6}$.

Pero a medida que pasaron las centurias, entre los siglos XIII y XVI, el declive de la población mudéjar se hizo cada vez más patente, pasando de un ochenta a un treinta por ciento. Además, a lo largo del XV los centros de enseñanza islámica se trasladaron desde las ciudades a las villas señoriales, ya que los señores, a cambio de rentas más altas o servicios adicionales, permitían la práctica de una fe islámica más viva que en la ciudad, habitada mayoritariamente por unos cristianos que manifestaban su fe de manera excluyente ${ }^{7}$.

Pero por distintos factores esa repoblación inicial fue insuficiente y a finales del año 1270, Jaime I realizó un nuevo llamamiento para lograr la llegada de nuevos cristianos del norte ${ }^{8}$. La movilidad poblacional en un escaso número de décadas fue considerable, lo que dificultó el asentamiento demográfico y la aparición de unas estructuras económicas y sociales que permitieran el fomento de los movimientos corporativos. Pero éstos, a pesar de todo, aparecieron.

Lo que este dato nos aporta en relación con la ciudad y las cofradías es la inminencia y la cercanía de tales fenómenos: 1270, nueva llamada a la repoblación; 1304, Tratado de Torrellas; 1329, explosión del movimiento confraternal.

En un tiempo histórico de seis décadas, dos generaciones posiblemente, se crean las condiciones necesarias para la aparición de una demanda

${ }^{4}$ P. LÓPEZ ELUM, La conquista y repoblación valenciana, p.127.

${ }^{5} \mathrm{La}$ presencia de otras comunidades religiosas aparecía en las ordenanzas de alguna cofradía de forma excluyente. Por ejemplo, entre los argenters (1418) los menestrales debían ser personas leales y naturales al rey, prohibiendo que se enseñara el oficio a judíos, moros o a esclavos.

${ }^{6}$ J. Hinojosa Montalvo, La morería de Elche en la Edad Media, Teruel, 1996, pp.7-8.

${ }^{7}$ M.D. MEYERSON, Un reino de contradicciones: Valencia 1391-1526, "Revista d'Història Medieval" (Los mudéjares valencianos y peninsulares), 12 (Valencia, 2001-2002), pp.16-19.

${ }^{8}$ P. LÓPEZ Elum, La conquista y repoblación, p.201. 
espiritual, profesional y solidaria que dio lugar a la solicitud de unos estatutos y ordenanzas que regulasen estas inquietudes ${ }^{9}$. Tal proceso no se extinguió con las primeras reclamaciones, sino que se expandió y se modificó a lo largo de la Baja Edad Media, para desarrollar, a finales del siglo XIV una serie de elementos que nos acercan a la modernidad, sobre todo en lo relativo a la gremialización.

\section{LA CONSOLIDACIÓN DEL FENÓMENO ASOCIATIVO}

A la par que se producía la construcción del reino de Valencia, surgieron una serie de fenómenos económicos, políticos y sociales entre los que se encontraría el asociativo: la necesidad de experimentar de manera conjunta unos usos religiosos y solidarios, y que estas prácticas permitieran a sus integrantes una cohesión jerárquica y una promoción externa, ya sea política, profesional o simplemente de representación social, de imagen social. En el caso valenciano, este fenómeno adquirió unas características concretas, sin renunciar a los elementos que aparecieron en otros puntos de la península y de Europa.

Un primer paso tuvo lugar entre 1245 y 1270. Jaime I constituyó el consell valenciano, introduciendo en él la participación de los artesanos. Su presencia en la estructura económica estuvo reconocida por la legislación foral y por los ordenamientos municipales. Es decir, que frente a la persecución que van a sufrir las agrupaciones de artesanos en momentos posteriores, la primera intención es de implicarlos en el juego político, como una forma de ordenar económicamente el reino. Tras un proceso de conquista militar, la Corona pretendía impedir el desplome del nuevo territorio, dando una serie de concesiones a aquellos sujetos económicos que podían incrementar su dinamismo.

A pesar de todo, estas agrupaciones no se presentaban como organizaciones profesionales, aunque ese reconocimiento llegó con el privilegio de 1283 que sancionó la participación corporativa. Aún así, la representación política vino condicionada por la importancia cualitativa de cada uno de los oficios en la economía urbana y por la presión cuantitativa. Pero esta presencia artesana no debe sobrevalorarse, ya que la mà mitjana ejerció un importante control sobre los oficios, la mà menor. Así, la reorganización municipal de 1283 impidió el acceso de los oficios al poder ejecutivo, es decir, limitó la posibilidad de un gobierno de las corporaciones. Esta situación fue variando a lo largo del tiempo. Entre 1347 y 1362, por ejemplo, los consellers de los oficios desaparecieron como consecuencia de la Guerra de la Unión, aunque volvieron a aparecer en esa última fecha,

\footnotetext{
9“Gracias al renacimiento del Derecho Romano , se pudo impulsar la práctica notarial y se fueron desarrollando y perfeccionando los mecanismos de control por la acción del Estado". J.A. BARRIO BARRIO Los privilegios reales. Centralización estatal y transmisión de la política real. Los cimientos del Estado en la Edad Media. Cancillerías, notariado y privilegios reales, en La construcción del Estado en la Edad Media, Alicante, 2004, p.123.
} 
quedando reducidos a dos por oficio. Entre 1371 y 1411 fueron los jurados de la ciudad quienes eligieron a los consejeros de los oficios, arrebatándoles así parte de sus prerrogativas. Estas fueron recuperadas momentáneamente bajo el reinado de Fernando I (1412), y perdidas definitivamente en 1419. Por lo tanto, la presencia constante de unos 80 consellers de los oficios en el consell tuvo un significado más institucional que político, dando lugar a un control social y económico desde arriba $^{10}$.

Un primer proceso dentro del mundo corporativo nos habla, por tanto, de su repercusión económica y política. Al mismo tiempo que se produjo la implantación de los menestrales en el territorio valenciano, nos encontramos con la creación de dos instituciones distintas, el oficio y la cofradía, que dieron forma a sus aspiraciones y reivindicaciones. Aunque desarrollaremos las dificultades que ofrecen estos términos en el siguiente apartado, hay que distinguir a los oficios (mesters o arts) como entidades aglutinadoras de los artesanos, con funciones económicas, técnicas y profesionales; mientras que las cofradías cubrían una serie de necesidades benéficas, asistenciales y religiosas, con escasas o nulas referencias al campo de lo profesional. A pesar de estas diferencias, los límites entre unos y otros conceptos resultan bastante imprecisos ${ }^{11}$.

Como estamos viendo, dentro de este periodo de construcción del reino hay un destacado desarrollo de elementos políticos, sociales y económicos. Pero no sólo aparecen estos componentes. En el contexto de las inquietudes espirituales se hizo necesaria una apropiación ideológico-religiosa del nuevo territorio, lo que incidió notablemente en la aparición del movimiento confraternal. La llegada de contingentes poblacionales cristianos compensó la presencia del sustrato mudéjar. La implantación de las parroquias en el mundo urbano y la aparición de las cofradías permitieron marcar una serie de usos sociales, de prácticas en las relaciones diarias de la urbe. El valor simbólico de transformar una mezquita en iglesia, o de señalar un territorio con una iconografía religiosa concreta, es una herramienta física y visible. Del mismo modo, la aparición de asociaciones religiosas que fomentaban una praxis cristiana entre los laicos era otra forma de estampar una impronta religiosa en el tejido urbano, con una serie de usos y costumbres que abarcaban las relaciones políticas, económicas y sociales.

Así, los oficios se fueron estructurando en las ciudades a medida que los artesanos se asentaron en el nuevo reino. Pero, al mismo tiempo, surgió una clara tendencia prohibicionista por parte de la Corona ante las corporaciones de oficio, lo que dio lugar a otras formas asociativas, a la aparición de cofradías, hermandades y asociaciones que anticipaban actitudes gremiales.

${ }^{10} \mathrm{P}$. IRADIEL, Corporaciones de oficio, acción política y sociedad civil en Valencia, en Cofradias, gremios y solidaridades, pp.260-279.

${ }^{11}$ J. CASTILLO; L.P. MARTÍNEZ, Els gremis medievals en les fonts oficials. Els fons de la Governació del Regne de València en temps d'Alfons el Magnànim (1417-1458), Valencia, 1999, p.18. 
Para comprender esta aparente contradicción de las autoridades reales, que en unas ocasiones promocionaban a los oficios y en otras coartaban sus formas de expresión, hay que remontarse al privilegio otorgado por Jaime I en el año 1266. En tal fecha, el monarca instituyó cuatro jurados para gobernar la ciudad de Valencia auxiliados por un consejo consultivo, consell general, del que formaban parte los prohombres artesanos. Sobre esta base los oficios comenzaron a organizarse dependiendo de su estatus profesional y de sus jerarquías. Además, en 1270, Jaime I concedió a cada oficio la facultad para elegir anualmente a dos veedores que inspeccionaran obras y fraudes. A continuación, en 1278, Pedro III estableció por primera vez una distinción entre las categorías sociales, y los jurados aumentaron a seis. En 1283 concedió a 15 oficios representación política expresa en el consell general. Todo ello impulsó considerablemente el movimiento corporativo en las últimas décadas del siglo XIII. En esta primera etapa aparecieron cofradías de devoción vinculadas a las iglesias. Sus integrantes permanecieron unidos a través de lazos de solidaridad y vecindad, ya fuera a partir de una capilla con su patrono, de un hospital o de las actividades vecinales ligadas a un barrio ${ }^{12}$.

Pero entre esta primera etapa y la segunda hay un paréntesis marcado por la prohibición. Esta interrupción viene descrita al inicio del segundo periodo, en 1329. En tal fecha, el rey Alfonso IV aprobó nuevamente los capítulos de la cofradía de çabaters anulando las disposiciones anteriores en las que se afirmaba:

\section{quia ex congregationibus in conuentiolis hominum non nunquam monopolia et illicita emergunt consilia que illicitis actibus ausum perbent serenissimus dominus Jacobus, recolude memorie rey Aragunum genitor, non confratrias omnis ciuitatis et regni Valeencie, excepta confratria que dicitur sia fa repbauit easqaum cassauit et garritauit ac perpetua sustulit sanccionem... ${ }^{13}$}

Los términos abuso, ligas, monopolios o la rivalidad entre las cofradías parecen estar detrás de estas prohibiciones, que son un hecho casi general en Europa occidental. Sin embargo, para algunos autores las prácticas económicas monopolísticas no estarían detrás de una medida tan drástica por parte del poder real. Habría que buscar una explicación jurídica y legislativa ante esta acción prohibicionista. Hasta finales del siglo XIII, el ascenso de las corporaciones de oficio tendría un reflejo político que permitió su participación en el gobierno municipal. Esta conquista benefició a los miembros de los oficios mayores en perjuicio de la vieja aristocracia nobiliaria y de la burguesía de la mà mitjana. La prohibición de la Corona sería la consecuencia

${ }^{12} \mathrm{P}$. IRADIEL, Corporaciones de oficio, pp. 264-266. Además, se observa una evolución en el trato de los monarcas de la Corona, dependiendo en ocasiones de la situación coyuntural. Jaime I controló el desarrollo de estas agrupaciones; mientas que Pedro III concedió privilegios a los oficios, lo que permitió su participación en el gobierno municipal. En cambio Pedro IV limitó las libertades asociativas como represalia por la Guerra de la Unión (1347-1349). Pero el mismo rey volvió a interceder por ellos durante la guerra con Castilla (1356-1365). Asś, en 1363 recuperaron la facultad de elegir a sus representantes en el consejo municipal, perdidas en $1349 . J$. CASTILLO y L.P. MARTINEZ, Els gremis medievals, p.24.

${ }^{13} \mathrm{ACA}, \mathrm{C}$, reg. 479 , fol. $167 \mathrm{r}$. 
de una alianza entre el poder señorial y el monárquico, que dio lugar a la represión del movimiento corporativo, fortaleciendo las iniciativas señoriales y la competitividad urbana ${ }^{14}$.

A partir de aquí, los oficios se vieron obligados a buscar otras formas de representación social, las cofradías devocionales y solidarias, iniciándose un lento proceso, que en algunos casos se encaminó hacia la gremialización, aunque la naturaleza del movimiento cofraternal valenciano no se reduce a una paso previo hacia el gremio, sino que por sí mismo tuvo entidad suficiente y autónoma ${ }^{15}$.

El punto de partida de esta segunda etapa fueron las concesiones de 1329. Como se puede observar en el siguiente cuadro, en dos años se aprobaron un total de siete ordenanzas de diversas cofradías, es decir que se trata de uno de los periodos de mayor concentración en torno a las autorizaciones otorgadas por la Corona, un acontecimiento sólo superado por el trienio 1391-1393.

\begin{tabular}{|c|c|c|c|c|c|c|c|c|c|}
\hline \multicolumn{8}{|c|}{ Ordenanzas aprobadas entre los reinados de Alfonso IV y Alfonso $\mathbf{V}^{\mathbf{1 6}}$} \\
\hline $\begin{array}{c}\text { AÑODE } \\
\text { APROBA- } \\
\text { CIÓN }\end{array}$ & $\begin{array}{c}1 \mathrm{e}+0 \\
7\end{array}$ & 1353 & 1368 & 13701371 & $1 \mathrm{e}+07$ & 13911393 & $1 \mathrm{e}+07$ & $1 \mathrm{e}+07$ & 14401443 \\
\hline $\begin{array}{c}\text { ORDENAN- } \\
\text { ZAS }\end{array}$ & 7 & 1 & 1 & 4 & 11 & 52 & 6 & 3 & 2 \\
\hline $\begin{array}{c}\text { PORCEN- } \\
\text { TAJE }\end{array}$ & $8 \%$ & $1,1 \%$ & $1,1 \%$ & $4,6 \%$ & $12,6 \%$ & $59,7 \%$ & $6,9 \%$ & $3,4 \%$ & $2,3 \%$ \\
\hline
\end{tabular}

Así nos encontramos con que la necesidad de fomentar las actividades económicas del reino y de lograr una estructura política estable planteaba esta situación contrapuesta para la Corona, con periodos de aceptación y periodos de rechazo de tales organizaciones.

En este segundo periodo la caballería entró en las magistraturas municipales y se derogó la prohibición de las cofradías de oficio. Parece que en este momento se consiguió un equilibrio entre los intereses señoriales y monárquicos, con las aspiraciones de los grupos económicos corporativos. Entre esta fecha y el inicio de la revuelta de la Unión (1347-49) las relaciones entre las corporaciones y el poder político vivieron "momentos conflictivos pero articulados". La Guerra de la Unión nos indica el poder alcanzado por

\footnotetext{
${ }^{14} \mathrm{P}$. IRADIEL, Corporaciones de oficio, pp. 266-267.

${ }^{15} \mathrm{La}$ oposición al funcionamiento de las cofradías en el siglo XIIII tuvo consecuencias en la siguiente etapa. La Iglesia se convirtió protectora de estas agrupaciones de laicos dedicados a la devoción y a la caridad según los estatutos redactados. Estas ordenanzas también se centraron en su propia organización interna, convirtiéndose en un factor destacado para aglutinar a la sociedad urbana. J.A. SESMA MUÑOZ, Cofradias, gremios y solidaridades en la Europa medieval, en Cofradías, gremios y solidaridades, 1992 , p.28.

${ }^{16}$ Fuente: ACA. Cancillería. Elaboración propia.
} 
las corporaciones de oficio. La derrota en este conflicto trajo consigo, sin embargo, la imposición de restricciones a la reunión de los oficios y la anulación de los privilegios de representación política artesanal. Estas restricciones se impusieron en las Cortes de 1349, aunque se suspendieron en $1362^{17}$.

Pero la gran explosión confraternal se produjo a partir de 1391. Durante tres años, el rey Juan I concedió cerca del $60 \%$ de las ordenanzas de las cofradías del reino aprobadas entre los reinados de Alfonso IV y Alfonso V. Una acumulación tan llamativa de reglamentos tuvo que responder, sin duda, a varios factores. Desde el punto de vista real, hay que destacar el elemento económico, ya que las ordenanzas concedidas entre los años 1392 y 1393 se otorgaron a cambio de una cuantía monetaria, algo inusual en el resto de documentos estudiados. Estas cantidades eran muy variables, desde los 20 florines de oro de Aragón (macips del pes real, Santa Lucía, bossers $i$ carders y taberners de Valencia, o San Jaime de Villareal) hasta los 100 florines de oro de Aragón (lauradors apellats del camí de Morvedre o teixidors de Valencia). En total fueron 45 las cofradías obligadas durante esos dos años a pagar una tasa a cambio de sus ordenanzas. La media fue de 43 florines por cofradía. Las necesidades de la Corona podían estar detrás de esta petición económica, pero en ningún momento se explicaba una diferencia tan amplia entre lo que se exigió a una cofradía y a otra. ¿Tal vez su potencial económico utilizado un baremo que desconocemos? ¿Tal vez por el número de cofrades inscritos, debiendo pagar más las hermandades más numerosas? ${ }^{18}$

Lo que parece claro es que a finales del siglo XIV el movimiento corporativo volvió a surgir con una gran intensidad, ya sea en su vertiente exclusivamente religiosa o profesional. El encadenamiento de epidemias en dicha centuria o la ruptura del linaje familiar hicieron necesaria la aparición de unas estructuras artificiales que minimizaran el miedo a la muerte solitaria frente a lo efímero de la familia natural ${ }^{19}$.

Esta cascada de ordenanzas aprobadas por la Corona abrió una nueva etapa, un periodo que enlazaba con la modernidad y que, por tanto, presentaba unas características muy destacables. Hasta finales del siglo XIV las motivaciones de las cofradías valencianas respondieron preferentemente a factores religiosos y asistenciales, aunque al mismo tiempo eran una manifestación externa de las inquietudes de los artesanos y por lo tanto también trascendieron sus necesidades económicas y políticas. Pero desde finales del Trescientos se observa un fenómeno nuevo que tiende a la

\footnotetext{
${ }^{17} \mathrm{P}$. IRADIEL, Corporaciones de oficio, pp.267-269.

${ }^{18}$ En el trabajo Las cofradías medievales en el reino de Valencia (1329-1458) aparece un cuadro más extenso con el nombre, la tasa a pagar y la fecha de la aprobación de las ordenanzas.

${ }^{19} \mathrm{El}$ nuevo marco de creación de las cofradías ya no era el barrio, la parroquia o los hospitales, sino directamente el oficio, canalizando así las formas de inserción social en la ciudad y la rivalidad entre los artesanos, ya fueran de un mismo oficio o de oficios afines. P. IRADIEL, Corporaciones de oficio, pp.269-270.
} 
gremialización de estas corporaciones. Sería la tercera, y última etapa medieval, de las cofradías.

Dicha transformación se hizo palpable en una serie de reglamentos que implicaron el control del oficio por parte de la cofradía ${ }^{20}$. Algunas de ellas parecen lógicas dentro del ambiente religioso que se promulgaba desde estas corporaciones, pero otras suponían un avance dentro de las competencias que tales hermandades habían adquirido hasta entonces. Por ejemplo, los corregers (1443) se veían obligados por las ordenanzas a cerrar el obrador y la tienda los domingos y días festivos, pero además debían tener la puerta abierta para que se viera que no trabajaban ni vendían sus mercancías. En un sentido parecido la cofradía de pellers (1392) ordenaba que si algún cofrade o familiar fallecía, el resto no podía trabajar en el obrador hasta que fuera enterrado. También estaba prohibido quitarle el aprendiz a otro compañero entre los maestres d'obra de vila a partir del año 1418.

En la cofradía de argenters (1392), bajo la justificación de su escaso número, los estatutos obligaban a todos los artesanos de dicho oficio a colaborar con la cofradía aunque no pertenecieran a ella. Pero en 1418 ya era obligatorio pertenecer a la hermandad. En cambio, otra agrupación, la de los de calaffats (1392) informaba que ningún miembro de la corporación podía impedir a nadie que obrara su oficio, según los fueros, excepto el rey o su lochtinent.

De este modo apareció uno de los primeros elementos de la gremialización de las cofradías: la obligación de pertenecer a la hermandad, aunque evidentemente no era el único. El control de la calidad de los productos artesanos a través de estas corporaciones llegó a partir de 1392. Anteriormente, como ya hemos indicado, Jaime I concedió a los oficios la capacidad de tener veedores para impedir fraudes y abusos, una cuestión que interesaba a las autoridades municipales y a los propios mesters, que obtenían así una personalidad jurídica propia ${ }^{21}$. Pero ya en el año 1392 las ordenanzas de la cofradía de armers de Valencia mencionaban este cargo, al igual que las de tinters del drap de la lana un año más tarde.

per lo mostacaf de la dita ciutat requets ne seran elegesquen e sien tenguts elegir dos prohomens dels dit offici de tintoreria en vehedors del dit offici de tintoreria, los quals dits dos vehedors sien presentats al dit mostacaf per los dits quatre maiorals de la dita confraria e iuren en poder del dit mostacaf de be e lealment vsar del dit offici de veedor ${ }^{22}$.

\footnotetext{
${ }^{20}$ Para el mundo artesano de la ciụdad de Dijon en la segunda mitad del siglo XIV, E. Husson considera que "ces règlaments insistent surtout sur le respect des modes de fabrication et sur le contrôle de la qualité des produits. Les prescriptions d'ordre technique sont particulièrment nombreuses dans les ordenances sur la serrurerie". E. HUSSON, Les métiers du bâtiment à Dijon sous le "mécénat" de Philippe le Hardi, duc de Bouroogne, en Les métiers au Moyen Age. Aspects économiques et sociaux. Louvain-La-Neuve, 1999, p.131.

${ }^{21}$ L. TRAMOYERES BLASCO, Instituciones gremiales. Su origen y organización en Valencia. Valencia, 1889 , pp. 314-315.

${ }^{22}$ ACA, C, reg. 1902, fol. 233 r. Ordenanza que se repite en el año 1417.
} 
En 1415 fue la cofradía de maestres d'obra de vila. En 1418 las cofradías de juponers $i$ vanovers y la de argenters. En la primera debían controlar posibles abusos o fraudes dando consejo a las autoridades municipales. En la segunda, los veedores podían inspeccionar los obradores siempre que quisieran. En estas ordenanzas, incluso, aparecía un tímido intento de establecer una reglamentación técnica en torno al trabajo con materiales preciosos como el oro y la plata.

Un último asunto para mostrar este proceso de gremizaliación de las cofradías se encuentra en el acceso a la maestría. Ciertamente, en este periodo aparecieron muy pocas referencias a tal cuestión. En la cofradía de argenters sólo se mencionaba que los macips deberían haber nacido en la señoría del rey y tendrían que pagar una tasa de 10 sueldos para la hermandad. Entre las ordenanzas de los maestres d'obra de vila sólo podía ser maestro quien hubiera trabajado anteriormente con otro maestro durante cuatro años y antes de alcanzar dicho estatus debía superar un examen. Lo mismo ocurría entre los corregers (1443), previo pago de 22 sueldos.

Todas estas ordenanzas parecen un intento de respuesta a la duplicidad institucional oficio-cofradía, que generaba inevitablemente conflictos en el mundo artesano. Lo curioso, a pesar de que finalmente no se hizo realidad, es que en 1453, Eximén Pérez de Corella, gobernador del reino, obligó a la unificación de oficio y cofradía y a la erradicación de los exempts, aquellos artesanos que no pertenecían a la cofradía. Esta propuesta obtuvo la adhesión total de los blanquers, pero la mayor parte de los oficios se quejaron porque esa medida iba en contra de la libertad de los artesanos de ingresar en las cofradías, así que el rey decretó su anulación. Pero la tendencia apunta a la fusión de oficio y cofradía ${ }^{23}$.

Por lo tanto, lo novedoso en las ordenanzas que hemos vistos a partir de 1392, no es que los oficios regularan la producción a través de veedores, la jornada laboral en los días festivos o el acceso a la maestría, sino que este control lo realizaran las propias cofradías y que sus estatutos empezaran a organizar tales asuntos, uniendo estas reglas (y las penalizaciones económicas en caso de contravenirlas) a las cuestiones que inicialmente habían motivado su aparición: culto a una advocación, solidaridad confraternal, beneficencia hacia los pobres de la ciudad, etc.

\section{COFRADÍAS, GREMIOS, HERMANDADES: EL ESPINOSO ASUNTO DE LA TERMINOLOGÍA}

Cualquier intento de analizar el movimiento corporativo se enfrenta a un problema básico: la existencia de tendencias similares en puntos muy lejanos de la Europa cristiana y, al mismo tiempo, las grandes variaciones que se observan en este fenómeno, ya sea por motivos espaciales, temporales, por

\footnotetext{
${ }^{23}$ J. CASTILLO y L.P. MARTíNEZ, Els gremis medievals, pp.26-39.
} 
las aspiraciones que manifiestan tales grupos o por el contexto en el que se desenvuelven. Esta realidad afecta necesariamente a las expresiones que utilizamos, es decir, a la carga terminológica que sirve de punto de partida para cualquier investigación, iniciándose así un debate sobre términos y contenidos que en ocasiones puede resultar estéril.

Esta discusión tiene una importancia relativa, e internarse en un concienzudo estudio sobre el significado de cada expresión puede llevar a ignorar otros muchos aspectos del rico movimiento corporativo.

Aún así vamos a exponer algunas líneas básicas dentro de esta cuestión, aunque sólo sea para distinguir las expresiones que se están utilizando a lo largo del presente trabajo. Algunas cuentan con ejemplos propios del reino de Valencia, pero otras completan su contenido con la experiencia asociativa de otros territorios.

A) Comenzamos por el final de la evolución de algunas de estas corporaciones. El término gremio es una etiqueta claramente definida pero inadecuada para época medieval. Sus características serían el proteccionismo y la defensa de los intereses de la elite dirigente ${ }^{24}$. Se trata de una expresión que encuentra su lugar en la época moderna, aunque ya hemos visto que a lo largo de la baja Edad Media aparecen algunos signos de un proceso de gremialización ${ }^{25}$.

B) Por mester u oficio podríamos entender aquellas corporaciones cuyos fines son netamente económicos y laborales, bajo el control y el reconocimiento de los poderes públicos, que en un primer momento decidirían o supervisarían cargos como alcaldes, jurados, alamines y veedores ${ }^{26}$. En Cataluña, por ejemplo, las cofradías y las corporaciones de oficio no constituyeron dos estructuras de integración sincrónicas. El movimiento confraternal arraigó en la primera mitad del siglo XI, pero la socialización profesional no es anterior a 1200. A pesar de esta diferencia cronológica no se deduce que las asociaciones económicas derivaran de las asistenciales, sino que tenían un origen distinto ${ }^{27}$.

C) Cofradías, confrarias o almoinas. Son los términos más utilizados entre las ordenanzas aprobadas por la Corona para el reino de Valencia entre 1329 y 1458. A pesar de esta aparente unidad terminológica, el contenido de los reglamentos nos acerca a realidades distintas. Aparecen así las cofradías religiosas como respuesta a las necesidades espirituales y devocionales de la

\footnotetext{
${ }^{24}$ J.A. SESMA MuÑOZ, Cofradías, gremios y solidaridades, p.24.

${ }_{25}^{25}$ Dans la Provence médiévale l'exercice du métier, l'ouverture d'un atelier ou d'une boutique sont libres et non soumis à des conditions restrictives. La réglamentation et le contrôle du travail relèvent de l'autorité communale et non d'une organisation corporative du métierr". N. COULET, Les confréries de métier à Aix au Bas Moyen Age, en Les metiers au Moyen Age, p.55.

${ }^{26}$ A. COLlantES DE TERÁN, Solidaridades laborales en Castilla, en Cofradías, gremios y solidaridades, p.115.

${ }^{27}$ A. RIERA I MELIS, La aparición de las corporaciones de oficio en Cataluña (1200-1350), en Cofradías, gremios y solidaridades, pp. 315-316.
} 
sociedad bajomedieval ${ }^{28}$. Las cofradías de oficio estarían formadas por miembros de un oficio concreto, o por cofrades de varios oficios distintos. Resulta evidente que las cofradías de oficio estaban formadas mayoritariamente por artesanos, pero posiblemente también sucedería lo mismo con las cofradías religiosas, o al menos por ciudadanos de un nivel social, unos intereses y unas inquietudes similares a los menestrales ${ }^{29}$. La diferencia estribaría en que el componente artesano sería el aglutinador y vertebrador principal para la creación de estas agrupaciones, mientras que en las religiosas sería el aspecto devocional ${ }^{30}$. Las formas de articulación entre cofradías y oficios responderían a tres modalidades: federación de oficios, cofradía-oficio o la identificación de un oficio con varias cofradías ${ }^{31}$.

Ampliando el espectro socio-económico, existen otros tipos de hermandades que no estaban integradas por representantes del artesanado valenciano, sino por otras ramas de la economía, por ejemplo, las formadas por agricultores. Entre ellas aparecieron las de lauradors jovers de Valencia, bajo la advocación de San Antonio (1392), la cofradía de lauradors apellats del camí de Morvedre (Valencia, 1392), lauradors de San Lázar del camí de Morvedre (1392), bracers de Valencia (1392), Santa María de Carmen del Lugar de Quart (1392), lauradors de Ruzafa (1393), lauradors de Villareal (1385), o Santa María y San Agustín de Alzira (1393).

Las circunstancias históricas y las inquietudes religiosas del bajo medievo dieron lugar además a la aparición de dos agrupaciones de judíos conversos. Tras el asalto a la judería de Valencia en el año 1391 se produjeron numerosas conversiones de rabinos, intelectuales y menestrales. La mayoría de estos conversos fueron artesanos -sastres, carpinteros, tejedores, tintoreros y sobre todo orfebres ${ }^{32}$. Estos conformaron dos corporaciones: San Cristóbal (médicos, plateros, especieros y mercaderes) y San Amador (sastres y juboneros). En el año 1420 se produjo la unión de dichas hermandades, tras una serie de pleitos y conflictos entre ambas.

\footnotetext{
${ }^{28}$ Los términos utilizados por las cofradías valencianas para designar a sus miembros eran pròceres, espanyats, personas miserables, prohombres honrats o bons homes, incluso quels confrares sien preueres o en sacres ordes constiuits. En Andalucía [J. SÁNCHEZ HERRERO, Reglas de hermandades y cofradías andaluzas. Siglos XIV, XV y XVI. Universidad de Huelva, 2002 , pp 35-36] las cofradías más antiguas eran las hospitalarias (1336), le siguieron las cofradias de santos (1353). A continuacion aparecieron las de Santa María y desde mediados cofradias de santos (1353). A continuacion aparecieron las de Santa María y desde mediados del siglo XV (1432) las cofradías de la Santísima Trinidad, que se fundaron también duran

29 “La distintion entre confrérie pieuse et confrérie professionelle n'est pas toujours clairament indiquée. Le première se constitue généralment avant la seconde et les règlments mettan autant 1 'accent sur les messes anniversaires, l'organisation des fêtes la répartition des

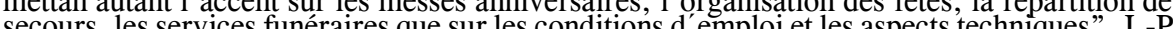
LEGUAY, Les métiers de l'artisanat dans les villes du duché de Bretagne aux XIVe et XंVé siècles, en Les métiers au Moyen Age, p.168.

${ }^{30}$ Todo ello sin olvidar que hasta comienzos del siglo XIV la palabra confratria no tenía buena prensa y que en los textos oficiales estaba unida a términos como colligationes, conjurationes, societates, amenazantes para las autoridades políticas y religiosas. J.A. SESMA Mữoz, Cofradias, gremios y solidaridades, p.26.

${ }^{31}$ J. CASTILLO y L.P. MARTÍNEZ, Els gremis medievals en les fonts, p.20.

${ }^{32}$ J. Hiñojosa MONTALVO, Los contrastes del siglo XIV (1327-1410), "Nuestra Historia", III (Valencia, 1980), p. 153
} 
Otra variante era el collegi dels cent ballesters de la ploma. Estaba formado por artesanos de distintos oficios que se encargaban de la guardia urbana. Entre sus privilegios se hallaba el derecho a portar armas.

En cuanto a las cofradías formadas exclusivamente por clérigos, únicamente en las ordenanzas de Santa María de Valencia (1371) se imponía que los cofrades fueran preveres o que tuvieran sagradas órdenes. Sin embargo en el año 1382 ya no se imponía restricción alguna a los que no tuvieran sagradas ordenes, siempre que los mayorales y consejeros laicos examinaran la petición del solicitante de común acuerdo con el prior, los mayorales y los consejeros clérigos de la cofradía. En cambio, en otros puntos de la península sí que surgieron cofradías, ligas y hermandades formadas exclusivamente por clérigos. Aunque no tuvieron en muchas ocasiones el respaldo de la jerarquía eclesiástica, siguieron el modelo de los cabildos catedralicios para cumplir con el culto divino y defender sus intereses. Los propios cabildos podían conformar hermandades, cofradías o compañías menores $^{33}$.

D) Ligas, monopolios o monipodios. Los oficios y mesters presentaban una naturaleza pública y quedaban integrados en los mecanismos de control social y económico de las autoridades. Las ligas y monipodios serían organizaciones de tipo privado e ilegal ${ }^{34}$. Existían por lo tanto agrupaciones al margen de cualquier autorización civil o eclesiástica y que presumiblemente se verían perseguidas por los poderes públicos.

E) Hermandades. Las agrupaciones con un claro componente religioso reciben alternativamente el nombre de cofradía o hermandad, lo que puede llevar a una confusión de contenidos y objetivos. Para distinguir ambos términos, los autores que han profundizado en el aspecto de la terminología han utilizado varios criterios.

El primero sería sincrónico: hermandad se refiere a las asociaciones de seglares católicos que rinden culto a una advocación y realizan obras piadosas bajo la regulación de unos estatutos. Las hermandades con culto externo (procesiones públicas) serían las denominadas cofradías. Esta distinción, aparentemente aclaratoria no evita cierta confusión referida a otras agrupaciones como las formadas por romeros, las que se dedicaban a realizar procesiones en los claustros de los conventos, o las encargadas de realizar un culto sacramental o penitencial.

El segundo criterio estaría referido al derecho canónico, que hace una distinción similar entre hermandades y cofradías, pero no incluye ninguna diferencia de contenido social. Sólo acepta la función espiritual y de culto, distinguiendo a su vez tres categorías: sacramental (culto a la eucaristía), de gloria (culto a una advocación de la virgen o a un santo) y de penitencia (pasión de Jesucristo o la virgen Dolorosa).

\footnotetext{
${ }^{33} \mathrm{~J}$.-L. MARTín, Hermandades y ligas de clérigos en los reinos hispánicos, en Cofradías, gremios y solidaridades, pp. 138-140.

${ }^{34}$ A. COllantes DE TERÁn, Solidaridades laborales, p.115. 
El último criterio, diacrónico o histórico, presenta diferencias espaciales y temporales. En la Alta Edad Media existiría una mezcla de elementos laborales y religiosos. A partir del XV las hermandades tuvieron una función predominantemente religiosa sin alejarse del movimiento gremial. La separación espiritual-laboral se produjo a partir del siglo XVII ${ }^{35}$.

F) Imprecisiones y aclaraciones. El esquema presentado no debe hacernos olvidar que la realidad corporativa es mucho más compleja y que la gran variedad de términos utilizados en la época (universitas, ministerium, artificium, confraria, almoina, offici, mester, o collegi) responde también a las relaciones entre los sectores productivos y la demanda urbana, con relaciones siempre cambiantes, pero también a la incapacidad de captar las nuevas realidades económicas, o al enmascaramiento ante las persecuciones de las autoridades municipales y reales ${ }^{36}$

La separación entre cofradía y oficio limitaba las relaciones entre estas agrupaciones encaminadas a la promoción social, la constitución de jerarquías, y la intervención política contando con un funcionamiento inestable. En este sentido, las cofradías de oficio aparecieron después del oficio, a iniciativa de sus prohombres. Las cofradías tendieron a confundirse con el oficio a finales del siglo XV, pero la monarquía trató de separar ambas dimensiones, por lo que buscaron otras conexiones ${ }^{37}$. Así es como aparecen las solicitudes de ordenanzas encaminadas al control del oficio por la cofradía.

\section{UNA PROPUESTA DE SISTEMATIZACIÓN}

Ante una variedad tal de formulaciones asociativas, ies posible esbozar un esquema de referencia que abarque matices geográficos y temporales, o que distinga la gran multiplicidad de intereses que confluyen en el fenómeno asociativo? Evidentemente, el contenido de este trabajo no es el de establecer un esqueleto básico para toda la Europa cristiana, sino tan sólo para el reino de Valencia. Además, este esquema no debería entenderse como punto de llegada, sino de partida para comprender el movimiento confraternal valenciano. Tendría que albergar elementos muy dispares, algunos ya pergeñados en los apartados anteriores, como los intereses sociales y económicos de los cofrades, las inquietudes espirituales, las necesidades comunales dentro del marco urbano, las imposiciones externas, las rivalidades profesionales o las aspiraciones políticas. Todo ello daría como resultado el siguiente gráfico:

\footnotetext{
${ }^{35}$ E. FERNÁNDEZ DE PAZ, Discusiones terminológicas sobre hermandad y cofradía, en Gremios, hermandades y cofradías ("Actas de los VII encuentros de historia y arqueología" II). San Fernando, 1991, pp.161-164.

${ }^{36}$ P. IRADIEL, Corporaciones de oficio, p.258.

${ }^{37}$ Ibídem, pp.260-263.
} 


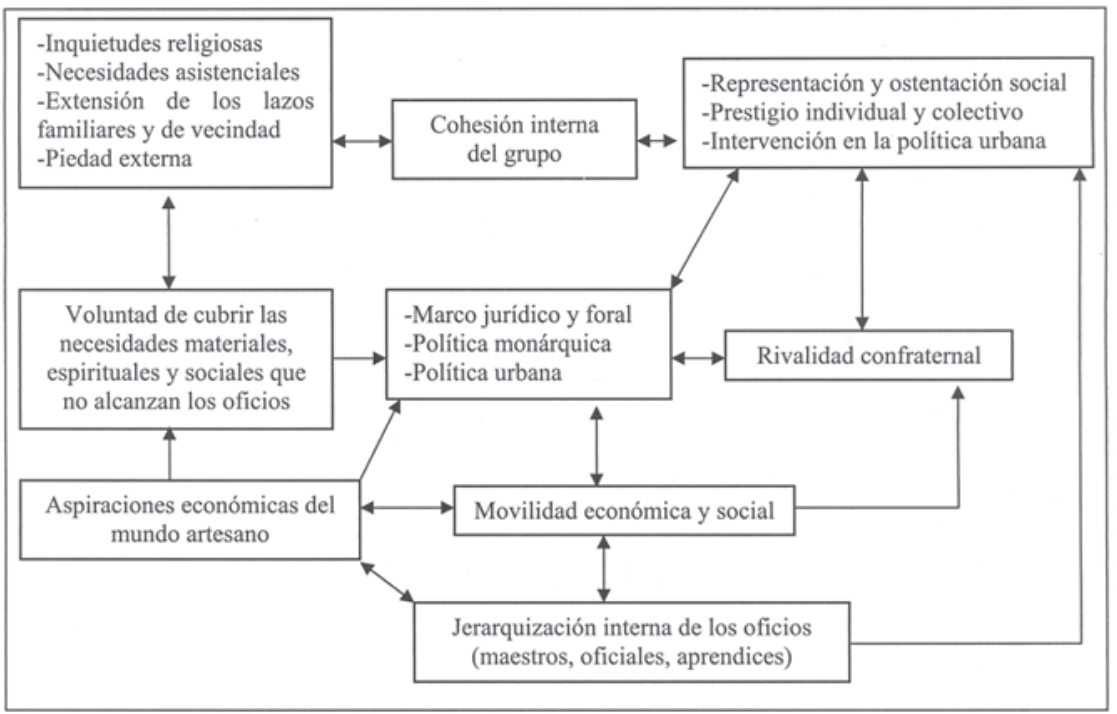

En este esquema, los recuadros reflejarían cada uno de los segmentos que motivaron la aparición de las cofradías o el resultado de su aparición. El entramado de flechas propondría un sistema de relaciones entre cada uno de los contenidos. La mayoría de ellas son bidireccionales, ya que los elementos constitutivos de las cofradías tienden a influir los unos en los otros, formando una compleja red de intereses, objetivos y motivaciones. Otras son unidireccionales, ya que representan meras consecuencias del recuadro anterior o influencias sobre el cuadro siguiente, aunque a su vez tienen repercusiones en otras expresiones confraternales, incidiendo en una trama en la que, en realidad, todo está relacionado con todo.

Pero este esquema, por sí mismo, resulta insuficiente. Necesita un desarrollo explicativo, aplicado a la materia de estudio de este artículo. Tanto los recuadros como sus relaciones pueden concentrarse en dos grandes apartados, no excluyentes, que definiremos de la siguiente manera:

-Religión, solidaridad y jerarquía como elementos de cohesión. La voluntad de cubrir una serie de necesidades que los oficios no podían alcanzar se refleja en las inquietudes religiosas, las necesidades asistenciales, la extensión de los lazos familiares y de vecindad, o la piedad externa, lo que servía como cemento de unión y de cohesión entre los cofrades. Todo ello tendría como punto de partida las aspiraciones económicas de los artesanos, la movilidad social y la jerarquización interna de los menestrales.

-Representación externa. Exhibición social. Una dimensión fundamental del movimiento asociativo era su repercusión en la urbe, no ya como 
intento de cubrir una serie de inquietudes espirituales y asistenciales, sino también como símbolo de ostentación social, de prestigio individual y colectivo, o como alternativa y camino hacia el control del gobierno urbano. Todo ello se manifestaba también en una rivalidad confraternal, ya fuera económica (dominio de la producción, de la mano de obra y del mercado), política (participación en la administración ciudadana) y social (exhibición de bienes y símbolos, tanto cívicos como religiosos o benéficos).

\subsection{Religión, solidaridad y jerarquía como elementos de cohesión}

"Está escrito: No sólo de pan vive el hombre, sino de toda palabra que sale de la boca de Dios" (Mt. 4,4)

Es evidente que la aparición de las cofradías en el reino de Valencia resultó una de las consecuencias del desarrollo de la ciudad medieval. Los artesanos buscaban un organismo de protección y fomento de sus intereses económicos. El acceso a las materias primas, el control de la producción, la maleabilidad del mercado, el régimen laboral en el interior de los obradores, la competitividad con otros oficios o con menestrales del mismo oficio, son piezas fundamentales para comprender las motivaciones de los artesanos. La movilidad social, las variaciones en el poder adquisitivo o la jerarquización de los mesters influyeron notablemente en las aspiraciones de maestros, macips y aprendices. Pero, como presume la cita de Mateo, "no sólo de pan vive el hombre". De este modo, el surgimiento de tales hermandades y su evolución se vieron impregnados de otros elementos igual de significativos.

Tal vez sea la necesidad psicológica del hombre, como ser individual, de sentirse parte de una comunidad de iguales; tal vez sea la respuesta a la desmembración de la familia natura ${ }^{38}$ y el deseo de extender los lazos fraternales a través de una familia artificial; tal vez sea la consecuencia de la predicación de las ordenes franciscana y dominica, o el resultado de la ocupación de un territorio habitado por mudéjares (durante mucho tiempo considerados como quinta columna enemiga), y que el dominio definitivo del reino, frente al enemigo interior y a los ataques desde Granada o del norte de África, sólo se conseguiría mediante la unión de los cristianos en hermandades religiosas ${ }^{39}$.

\footnotetext{
${ }^{38}$ En Aragón, el asociacionismo gremial era la única manera de acceder al gobierno local, mientras que el matrimonio se convertía en el núcleo del taller artesano, en la unidad de producción básica y en un medio de promoción social. De ahí que la Iglesia quisiera intervenir cada vez más en su regulación. El taller familiar era el centro de la producción artesana y una "micro sociedad" donde aparecían representadas situaciones sociales dispares: asalariados, esclavos, sirvientes y aprendices. D. GONZÁLEZ SEGURA, El mundo de los artesanos medievales en Aragón a propósito de un proceso contra el pelaire Miguel Florín (1488), "Actas del II Simposio de jóvenes medievalistas". Lorca, 2004, p.69.

${ }^{39}$ La primera solidaridad en la sociedad medieval era el linaje, restringido a las familias con poder, que mantenían un orden interno muy rígido, construyendo clientelas y creando lazos poder, que mantenin un orden interno muy rígido, construyendo clientelas y creando lazos artificiales con personas ajenas al propio clan, es decir, solidaridades verticales. Otras solidaridades eran las corporaciones de oficio, las convivencias de los estudiantes universitarios, las comunidades rurales y las asociaciones coyunturales de maleantes. Pero dentro de ellas también podían observarse relaciones de insolidaridad. En las las comunidades rurạles, el marco lógico era la parroquia, el concejo o la familia, dedicadas a la ayuda en los trabajos agrícolas,
} 
Lo cierto es que el resultado de todas estas variables nos da un interés palpable en organizarse como hermanos, como familia cristiana ${ }^{40}$, lo cual no oculta disensiones ni rivalidades internas, como demuestra que la mayoría de las ordenanzas vengan acompañadas de un anexo punitivo para multar a los cofrades desobedientes o díscolos ${ }^{41}$.

Hablar de un estereotipo de cofrade sería muy aventurado, pero los reglamentos informan con precisión de algunos condicionantes que se deben de cumplir, primero para entrar en la hermandad, y luego para seguir correctamente una vida cristiana.

En este ámbito, la buena fama era fundamental para ser un cofrade más, y no en el sentido de popularidad o notoriedad, sino en el de reputación o de honra. En muchas cofradías, los mayorales debían atestiguar previamente la fama, vida, condición y hasta la conversación de los aspirantes (absténganse los blasfemos). No debían aceptar a nadie que tuviera fama de ladrón, homicida, adultero, jugador, adivino, que fuera soltero, alcahuete, que jugara a escondidas, que acudiera a las tabernas o que se embriagara públicamente ${ }^{42}$. Ejercer la prostitución, vivir en concubinato, tener esposa y amiga de forma pública impedían el acceso y se prohibía entre los cofrades ya inscritos. De esta manera, la vida pública, o mejor dicho semi-pública de las cofradías, marcaba unas pautas de vida privada. Esto era necesario para la cohesión del grupo dentro de unas coordenadas y una mentalidad cristiana, fomentadas por las predicaciones de las órdenes religiosas y por personajes como San Vicente Ferrer. Es notorio que el individuo quedaba solapado al grupo, aunque no desaparecía en él, ya que el gran número de multas impuestas a los infractores podría ser una señal de un notable índice de infracción ${ }^{43}$.

Esta cohesión tiene varias vertientes. Por una parte, fomentaba la unidad interna entre los hermanos, y esta unidad era una fuerza cuya proyección externa veremos en el siguiente apartado. Por otro lado, era una forma de control social que interesaba a las autoridades reales y municipales,

la asistencia en los acontecimientos de la vida (matrimonios, nacimientos, fiestas, etc.) y al socorro mutuo en las desgracias (muertes, pérdidas de cosechas, muerte de los animales, etc.) J.A. SESMA MUÑOZ, Cofradías, gremios y solidaridades, p. 29.

${ }^{40}$ En cada núcleo urbano, el aumento de artesanos que se agrupan para convivir muestra que en el mundo medieval nadie se planteaba la posibilidad de vivir solo. Ibídem, pp.20-21.

41 "Les antagonismes entre riches et pauvres appartenant à une même corporation étaient devenus irréconciliebles. Au-dessus de la majorite des maîtres artisans s' était établi un petit gruope de patrons puissants, des artisans-marchands, dess entrepreneurs; en bas, des artisans pauvres, des hommes et des femmes. Plusieurs corporations étaient structurees à la manière aisés et prêtaient de l' argent à ceux quien avaient besoin" K. SIMON-MUSCHEID, Les documents normatifs et les "vécus" d'aprés les inventaires. Le cas de Bâle et de la région du Haut-Rhin, en Les métiers au Moyen Age, p.320.

${ }^{42} \mathrm{ACA}, \mathrm{C}$, reg. 1894 , fol. $19 \mathrm{r}$.

${ }^{43} \mathrm{La}$ vecindad era el requisito necesario para formar parte de la comunidad local en las villas y ciudades. Era necesario tener la condición jurídica de vecino para disfrutar del derecho urbano (franquicias y privilegios), y participar en la administración de los intereses jurídicamente a sus habitantes y obligaba a prestarse ayuda contra los extraños al grupo. J.I. RUIZ DE LA PEÑA SOLAR, Las solidaridades vecinales en la Corona de Castilla (Siglos XII-XV), en Cofradías, gremios y solidaridades, pp.64-67. 
un elemento que, combinado con el anterior, no debe hacernos olvidar que podía desembocar en todo lo contrario, como demostrarían el conflicto de la Unión (1347-1349) y las Germanías en el XVI ${ }^{44}$.

Pero la cohesión no se conseguía tan sólo con cofrades de buena fama y condición, había que trabajarla en terrenos muy diversos. Ahí es donde los estatutos mostraban una serie reglamentos que tenían como objetivo organizar administrativamente la almoina, regular las formas de culto religioso y establecer las pautas asistenciales básicas entre los cofrades. Detrás de estas ordenanzas, y de su significado inicial, aparecía el deseo, o la intención, de estructurar la cofradía, de darle una unidad y una consistencia que le permitiera cubrir todos sus objetivos.

En este sentido, uno de los aspectos más reglamentados era la organización administrativa de la hermandad, basada en el capítulo, es decir, en la reunión de todos los cofrades a partir de unas fechas y unos lugares establecidos habitualmente en las propias ordenanzas. La función del capítulo era administrar la cofradía. La obligatoriedad de asistir al mismo se exponía claramente en los reglamentos. El grado de control del capítulo por parte de las autoridades reales o municipales era variable, no seguía una línea coherente, sino que cambió a lo largo del periodo como cambian las relaciones cofradía-Corona-municipio ${ }^{45}$. La ausencia era multada con pagos en cera (para la luminaria de la advocación), en metálico, o incluso con la expulsión en alguna cofradía si se era reincidente.

Era necesaria una estructura administrativa interna coherente y bien reglamentada para tener la dimensión social adecuada. Al ser el capítulo el núcleo de la organización, nos encontramos ante un gobierno colegiado en el que sobresalían una serie de cargos específicos. Entre ellos destacaba el prior, un cargo religioso, y los mayorales, dedicados a formar los turnos para velar a los enfermos, evitar disputas entre los cofrades, cobrar cuotas y multas, etc. Los consejeros ayudaban a los mayorales, mientras que los andadores eran empleados de la cofradía dedicados a avisar a los cofrades para las reuniones del capítulo, sepulturas, aniversarios y otras tareas.

En cuanto a la forma de elegir tales cargos, podían utilizar dos modalidades. La mayoría de las cofradías se decantaban por un sistema democrático en el que los cofrades se reunían en capítulo y participaban en la elección de los regidores pudiendo ser seleccionados los nuevos mayorales de entre todos los presentes. En algunas cofradías podían intervenir en la elección

${ }^{44}$ En 1378, la sublevación de los artesanos florentinos es una muestra de la toma de conciencia de su condición social hasta llegar a reclamar la particinación en el gobierno de la ciudad. CG. CHERUBINI, I lavoratori fiorentini della lana fra solidarieta di mestiere e primo capitalismo, en Cofradías, gremios y solidaridades, p.108.

${ }^{45} \mathrm{En}$ Castilla, la relación entre las autoridades reales y las agrupaciones solidarias bascularon entre varios límites: el poder público indujo una conciencia de grupo imponiendo comportamientos grupales, pero también tomó medidas para frenar estos comportamientos comportamientos grupales, pero también tomo medidas para trenar estos comportamientos solidarios, limitando el monopolio económico y laboral. También influyó la existencia o no de una conciencia de grupo dentro de los oficios (ya que algunos artesanos se mostrarían más emprendedores que otros). Al no canalizarse la solidaridad por medio de los oficios, la existencia de las cofradías tendrían un mayor sentido. A. COLLANTES DE TERÁN. Solidaridades laborales, pp.116-122. 
los mayorales del año anterior, aparte de los cofrades. La segunda forma era más elitista. La elección se encargaba a los mayorales salientes junto con otros cargos específicos de la cofradía.

Uno de los deberes del cofrade era el pago (semanal, mensual o anual) de una serie de cuotas para sustentar a la cofradía. Esta obligación se constata desde mediados del siglo XIV pero no aparece en las ordenanzas anteriores.

$\mathrm{Si}$ estos deberes resultaban básicos para cubrir las necesidades administrativas y pecuniarias de la almoina, la comida de hermandad era una obligación irrenunciable. Se trataba una o varias comidas al año entre los miembros de la hermandad con el fin de que estrecharan lazos de amistad y buena voluntad entre ellos. Pero el menjar también podía derivar en tumultos y conflictos, ya fuera entre los miembros de la hermandad o como expresión de las aspiraciones de los oficios. Para controlar estas peligrosas actuaciones, las ordenanzas regulaban el número de comidas anuales. En la mayoría de los estatutos tan sólo se permitía una vez al año, pero en otras se especificaba un número mayor, e incluso se daba libertad de convocatorias. Eso sí, la obediencia a los mayorales, el buen comportamiento durante las comidas y las multas que se derivaban de la infracción de estos asuntos se recogen ampliamente en los reglamentos.

Pero los elementos de unión más significativos eran, como no podía resultar de otro modo, el religioso y el asistencial ${ }^{46}$ En primer lugar era necesario elegir una advocación a la que rendirle culto. Dos eran las fuentes principales entre las cofradías valencianas, el santoral y las advocaciones de la virgen María, aunque también nos encontramos con el culto a la Vera Creu, al Corazón de Cristo y a la Santísima Trinidad. Sin embargo, alrededor de 28 $\%$ de las cofradías no presentaba en sus ordenanzas ninguna advocación concreta.

El culto más extendido era el de ofrecer un amplio repertorio de luminarias (ya fueran cirios, candiles, lanteas, etc.) Esta inversión espiritual en luminarias se dedicaba principalmente a los patronos, y se instalaban en las parroquias urbanas o en las capillas confraternales. De este modo, las parroquias y la vecindad aparecieron como el núcleo inicial de confraternización en el reino de Valencia, como simiente para el establecimiento de lazos y vínculos en el ámbito del mundo urbano y artesano. Pero en realidad no es un caso único. Lo mismo sucedió en otros territorios peninsulares. En la

${ }^{46}$ Fueron varios los factores que influyeron en la aparición de una nueva sensibilidad espiritual: la difusión de una religiosidad que rompía con la anterior, demasiado clerical; la imposición de una sociedad cada vez más del individualista; el sentimiento de culpa; las predicaciones regulares o extraordinarias (como las de San Vicente Ferrer) que se unían a los sermones, al teatro religioso, al modelo de la vida de los santos, o el deseo de mayores conocimientos teológicos por parte de los seglares. Todo ello llevó a una crítica sobre la función sacerdotal, sus privilegios, sus bienes materiales, su jerarquización crica areciendo una función sacerdotal, sus privilegios, sus bienes materiales, su jerarquizacion, apareciendo una teologia favorable al laico en la reforma del XVI. Surgieron nuevas devociones (al Cristo dolorido o al niño Jesús y a la virgen). Pero lo más importante es que ante esta nueva sensibilidad, la piedad oficial no satisfizo del todo a los espíritus más sensibles, de ahí la aparición de movimientos heréticos desde el siglo XIII. A. FRANCO SILVA, La religiosidad popular en la baja Edad Media, en ,Gremios, hermandades y cofradías ("Actas de los VII encuentros de historia y arqueología”, I, San Fernando, 1991, pp.13-17. 
Corona de Castilla, por ejemplo, las comunidades rurales se organizaron en torno a la parroquia, estableciendo vínculos solidarios nacidos de la vecindad, convirtiéndose en la base institucional de la vida local. La vecindad se superpuso al parentesco a la hora de crear corporaciones o cofradías profesionales, basadas en la piedad o en el ejercicio de la caridad. A partir del siglo XII, la parroquia y la feligresía se convirtieron en la célula básica de convivencia rural y urbana, articulando la organización administrativa. Pero además, los concejos con capitalidad urbana extendieron su jurisdicción a un espacio alfocero poblado de aldeas organizadas en feligresías, incluso los concejos rurales se presentaron como entidades supraparroquiales ${ }^{47}$.

Las luminarias dedicadas al culto también se utilizaban de una manera amplia en uno de los acontecimientos que fue el origen y la motivación más importante de algunas de estas hermandades: el entierro de los cofrades. Esta demanda de luminaria hacía que muchas de las multas impuestas a los integrantes de las almoinas fuesen en cera, al igual que algunas de las cuotas que debían pagarse a las hermandades. El grado de meticulosidad se extremaba tanto que incluso se regulaba el peso de los cirios (media libra o una libra), el color (cera blanca), la ropa con la que se acompañaba al difunto $^{48}$, e incluso la forma de acompañar al difunto ${ }^{49}$.

Todos estos elementos nos hablan de un intento de normalizar lo trascendente, ya sea la santidad, como ejemplo del recto vivir cristiano, como modelo a seguir, o como intercesión ante la divinidad. También se trataba de un intento de ritualizar la muerte, de convertirla en un suceso ordinario, no extraordinario, para que no supusiera una ruptura, para que no desgajase la línea generacional que permitía mantener los esquemas sociales, algo que sucedía inevitablemente en épocas de grandes mortandades como la Peste Negra, en la que el continuo social se veía desarticulado. ${ }^{50}$ El hecho de una muerte individual, la tragedia de esta pérdida, el dolor de la familia o el drama económico que ese fallecimiento podía suponer, se compensaba mediante el rito, que mantenía las estructuras aunque el individuo hubiese desaparecido. Las oraciones por su alma estaban reguladas en las ordenanzas para que los cofrades rezaran un numero concreto, y no menos de ese número. De esta manera intentaban que el hermano fallecido alcanzara las estancias celestiales lo antes posible, y su paso por el purgatorio fuera de menor duración.

\footnotetext{
${ }^{47}$ J.I. RUIZ DE LA PEÑA, Las solidaridades vecinales en la Corona de Castilla, pp. 54-58.

${ }^{48}$ Existía una gran variedad: en alguna cofradía se prohibía llevar espardeñas, calzas o çarboix, un gorro que portaban los musulmanes ricos y algunos cristianos. En otras era obligatorio el drap de la cofradía, mantos, gramalles o capirons (cuyo color cambiaba según la hermandad).

${ }^{49}$ En algunas cofradías, sus miembros debían acudir primero a la casa del difunto y acompañarlo a la sepultura. En otras, debían acompañarlo a la iglesia para oír misa y regresar después a la casa de donde hubiera partido la comitiva. Los mayorales podían elegir a diez hombres para llevar el cuerpo hasta la iglesia y el cementerio. La presencia de frailes en los sepelios permitía solemnizar el acto y darle el sentido religioso que las cofradías pretendían.

${ }^{50}$ Lo que Jean Delumeau definió como "una ruptura inhumana”.
} 
La idea del purgatorio surgió en el siglo XII y contó una gran expansión en la centuria siguiente. La aparición de la clase media en la sociedad medieval implicó un cambio de mentalidad acerca de la vida terrena y la vida del más allá. Los Padres de la Iglesia ya hablaban de la existencia de pecados "veniales" o "cotidianos" que se podían redimir para alcanzar el cielo, pero fue en el siglo XII cuando el purgatorio apareció como un lugar definido entre el cielo y el infierno ${ }^{51}$.

Además de esta ayuda desde los vivos para que los muertos abandonaran lo antes posible el purgatorio, las oraciones y los ritos servían de consuelo y unidad para los que aún quedaban con vida. Eran un refugio psicológico y social para los que no habían iniciado el tránsito hacia la otra vida, y por lo tanto, un medio más de cohesión entre los cofrades ${ }^{52}$.

Pero ninguno de los elementos de unidad interna resulta tan significativo como la fiesta de la advocación bajo cuyo nombre se hallaba la cofradía. La finalidad de los actos que se desarrollaban en torno al patrón de la hermandad era unir fraternalmente a los cofrades bajo la concepción cristiana que movía a estas asociaciones. Las misas en honor al patrón, las oraciones, las celebraciones de las vísperas, el recuerdo de los cofrades difuntos, llenaban el calendario de eventos obligatorios para todos sus integrantes, salvo casos excepcionales como enfermedad o no encontrarse en la ciudad a lo largo de esa jornada. El día después de la fiesta de la advocación se celebraba el aniversario. En él se oficiaban misas de réquiem, se rezaban las oraciones (sobre todo el Padrenuestro y el Avemaría) o se recitaban los salmos penitenciales con el fin de obtener para los cofrades difuntos la salvación eterna y disminuir su estancia en el purgatorio.

Aparte de estas celebraciones religiosas, las cofradías también encargaban y pagaban misas que en algunos casos debían ser cantadas. Solían tratarse de fechas especiales como fiestas, reuniones de capítulos, el día de la comida, etc. La precisión de estas manifestaciones religiosas no debe hacernos olvidar el limitado interés de los capítulos por obligar a los cofrades a recibir los sacramentos. Esto se debía al escaso deseo de superarse devocionalmente $\mathrm{y}$ al intento de cumplir únicamente con las formas de culto establecidas ${ }^{53}$.

Todos estos lazos religiosos se extendían a los miembros de sus familias y en algunas ocasiones a cuantos vivieran bajo su techo, como demuestra la obligación de acudir al entierro de los familiares o de rezar oraciones y celebrar misas de réquiem por su alma.

Estos elementos espirituales derivaban de las transformaciones religiosas que se extendieron por Europa durante los siglos XIV y XV, dando lugar a unas inquietudes nuevas que no se detuvieron en tales organismos,

${ }^{51}$ J. LE GoFf, El nacimiento del Purgatorio. Madrid, 1985, pp. 9-17.

${ }^{52} \mathrm{La}$ garantía de la sepultura era un privilegio derivado del ejercicio de la profesión, siguiendo el ejemplo de la familia en la aristocracia. R. GRECI, Economía religiosita, politica. Le solodarietà delle corporazioni medievali nell'Italia del Nord, en Cofradías, gremios y solidaridades, p.86.

${ }^{53} \mathrm{M}$. LOP CATALÀ, La predicación y las cofradías valencianas, siglos XIV-XV, "Boletín de la Sociedad Castellonense de Cultura", LVIII/1 (1982), p.52. 
dirigidos o controlados por la Iglesia oficial. De ellos, además, resultaba una consecuencia con importantes repercusiones sociales: el establecimiento de unos vínculos solidarios y asistenciales entre los hermanos cofrades, unos lazos regidos por el concepto cristiano del amor fraternal.

La cofradía se convirtió así en un marco de ayudas mutuas, ya sean terrenas o espirituales. Las divisiones internas no desaparecieron con tales acciones. La diferencia de poder adquisitivo, de representación social y política, de capacidad económica en los obradores, o la existencia de estratos laborales (maestros, oficiales y aprendices), se mantuvo a pesar de la sensación igualadora que puede ofrecernos el término hermandad. Pero las ayudas espirituales y solidarias sirvieron de aglutinante para las distintas aspiraciones que dividían a los maestros entre sí y a estos con los macips. No servían de transformación social, pero integraban dichas diferencias, las hacían aceptables y necesarias, al tiempo que las suavizaban ${ }^{54}$. Para P. Iradiel, los cuerpos de oficio han proporcionado una imagen estática de la actividad laboral. Por ello cuestiona el carácter armonioso de las relaciones entre los maestros y los trabajadores, entre maestros de un mismo oficio o de diferentes oficios. Además, una enorme cantidad de artesanos quedaba fuera de ambas estructuras. El sistema era muy permeable al ingreso de artesanos no autóctonos, y la transmisión intergeneracional del oficio por herencia era extremadamente limitada por la alta mortalidad y por la aparición de nuevas profesiones para los hijos de los artesanos más acomodados ${ }^{55}$.

Surgen así una serie de capítulos asistenciales referidos a aspectos muy diversos, ya que trataban de abarcar las distintas problemáticas que aparecían en la multiforme sociedad urbana. El más común de estos capítulos era acompañar al cofrade enfermo a lo largo de su enfermedad, estableciéndose turnos entre los integrantes de la hermandad para tal efecto. La asistencia se extendía a los cofrades caídos en pobreza. Incluso, en algunas cofradías se ayudaba a aquellos que por vejez no podían llevar a cabo sus trabajos. En otras se ayudaba a los huérfanos o a las mujeres de los cofrades caídos en pobreza.

Una serie de capítulos solidarios eran consecuencia de la situación geográfica y social valenciana. Al ser un territorio fronterizo con Castilla, y cercano al reino nazarí de Granada, no eran extraños los asaltos y secuestros. Por ese motivo las cofradías solicitaban licencia para ayudar y rescatar a aquellos cofrades que per sos pecats o per desastre cayeran en cautividad. Algunas cofradías solían imponer una tasa para que todos los cofrades ayudaran económicamente en caso de que algún hermano resultara cautivo.

\footnotetext{
${ }^{54} \mathrm{Al}$ estudiar las cofradías de Barcelona, Bonnassie consideraba que eran un cuerpo de maestros de oficios, donde los oficiales eran miembros secundarios. P. BONNASSIE, La organización del trabajo en Barcelona a fines del siglo XV, Barcelona, 1975 , p. 36 . En las ordenanzas de las cofradías valencianas no se ven reflejadas claramente estas differencias entre maestros y oficiales, aunque sí aparecen dobles cofradías para un mismo oficio dependiendo de si se forman a partir de maestros o de oficiales: maestres d'obra de vila, maestres peraires y maestres texidors, macips peraires, macips texidors, macips del pes real, joves cabeteis $i$ custiners y lauradors jovers.

${ }^{55} \mathrm{P}$. IRADIEL, Corporaciones de oficio, pp. 273-277.
} 
Pero las cofradías no sólo estaban presentes en los momentos trágicos y difíciles de la vida, también en los momentos de alegría: fiestas de la advocación, comida confraternal y esponsales. Acudir al matrimonio de un cofrade o de un miembro de su casa era una muestra más de unión, de relación familiar. Incluso si el cofrade era pobre y no podía casar a su hija, los mayorales debían ayudarle con dinero de la caja común.

También se regulaba la cuestión del préstamo de dinero entre los propios hermanos en dos de los casos estudiados. Entre los macips del pes real de Valencia (1392) si algún pleito se originaba por cuestiones monetarias, o por cualquier otro tipo de cuestión civil, los mayorales podían intervenir para garantizar la paz y el orden, de lo contrario podían expulsar a los litigantes. En la cofradía de San Vicente (1380), si algún cofrade debía dinero a otro, por un préstamo o por cualquier otro motivo, durante los tres días de la fiesta de la cofradía no podía pedirle nada al deudor para que reinara la concordia.

Todas estas actitudes reflejan un deseo apremiante de unidad y cohesión, primero como respuesta a las inquietudes espirituales del momento, pero también como forma de afrontar de manera conjunta los avatares de la vida, e incluso como palanca de fuerza, ya que cuanto mayor fuera la unidad interna, mayor representación y poder social podían pretender, como vamos a ver en el siguiente apartado.

\subsection{Representación externa. Exhibición social}

La visión que las cofradías tenían de sí mismas, o al menos, la visión que querían exteriorizar al resto de la ciudad y del reino a través de las ordenanzas era de organizaciones religiosas y benéficas centradas en el culto, la caridad, la ayuda a cautivos y enfermos, y el entierro de los cofrades. En las motivaciones de sus ordenanzas nunca aparecían referencias ni intenciones de acceder al gobierno municipal, o el deseo expreso de fomentar la economía urbana en provecho propio, aunque ya hemos visto la importancia que fueron adquiriendo los capítulos profesionales o gremiales a partir de $1392^{56}$. Sin

\footnotetext{
${ }^{56} \mathrm{En}$ Italia, de la unión entre las asociaciones de menestrales y las autoridades públicas a la hora de crear estas agrupaciones derivó en una fuerte orientación política. [GRECI, R. Economia, religiosità, politica, p.80.] En cambio, en Castilla, las cofradịas de oficio no servían para promover a ninguno de sư integrantes a cargos de alcalde o regidor. El acceso de los hombres de negocio a los concejos era debido a sus "carreras individuales". [J.M. MONSALVO Los artesanos y la política en la Castilla Medieval. Hipótesis acerca de la ausencia de las corporaciones de oficio de las instituciones de gobierno urbano, en Historia social y ciencias sociales ("Actas del IV Congreso de Historia Social de España", Lleida, 2000), pp. 296-298. En el País Vasco, las disputas fueron constantes entre las cofradías y los concejos por temas diversos: el control de las decisiones económicas y fiscales de los gobiernos locales, desconfianza de loo de las decisiones economicas y fiscales de los gobiernos locales, o la descontianza de los concejos ante estas agrupaciones (E. GARCIA FERNAANDEZ, Las cofradias de oficios, en el País Vasco durante la Edsad Media (1350-1550)., "Studia Historica. Historia Medieval", 15 (Salamanca, 1997), p.32.] Mientras tanto, en Lieja "les métiers profitent de la déstabilisation qui frappe le pouvoir ecclésiastique et l' elite socio-économique pour revindiquer une part de l'autorité communale" [XHAYET, Le rôle politique des métiers liégeois à la fin du moyen âge, en Les métiers au Moyen Age, 1994, p.362]
} 
embargo, estos intereses no se encontraban tan alejados de su voluntad como nos harían pensar los reglamentos aprobados por la Corona.

En realidad, la aparición de las cofradías fue una consecuencia de las limitaciones impuestas por la las autoridades reales y municipales a los oficios en el ámbito político. No hay que olvidar que durante la segunda mitad del siglo XIII el control del poder municipal hizo que los oficios se considerasen alternativa a los caballeros y burgueses. Estos, con el apoyo de la monarquía, adoptaron medidas restrictivas. En Valencia quedaron prohibidas la mayoría de las asociaciones de menestrales. El control impuesto por las autoridades municipales derivó en la aparición de una minoría dirigente, los maestros, incorporados al poder municipal ${ }^{57}$.

Al no tener el control ejecutivo del gobierno ciudadano, los artesanos derivaron sus aspiraciones sociales por otros caminos. Las cofradías no permitieron a sus integrantes el acceso directo al poder político, pero si les dio una representación social, una imagen pública de prestigio y de influencia, es decir, una forma indirecta de participar en el juego político como grupo de influencia (utilizando una expresión actual). De ahí la insistencia anterior en la cohesión interna, que les permitía cumplir sus objetivos religioso-asistenciales y tener una mayor capacidad de presión.

Muchas de sus ordenanzas iban encaminadas en este sentido. No sólo respondían a las inquietudes espirituales del hombre medieval, a cubrir las necesidades materiales mediante lazos solidarios y grupales, sino también a incrementar el prestigio social y la promoción de cofrades y cofradías, entendidos al mismo tiempo en sentido individual y colectivo. Las aspiraciones externas de las corporaciones se manifestaban de muy diversas formas: símbolos que les dieran una imagen pública de poder, ostentación de bienes y riquezas, actos de caridad para con los marginados de la urbe, puestos preferentes en celebraciones cívicas y religiosas, etc.

En este último caso hay una gran variedad de ejemplos como sería la colocación de las capillas corporativas en las iglesias principales o el lugar ocupado durante las procesiones, mostrando así su presencia en la vida pública. Eran demostraciones de la penetración de los laicos en el dominio de la Iglesia y de su presencia activa en la vida económica ${ }^{58}$.

En el caso concreto de la ciudad de Valencia la jerarquía social de los oficios se hacía pública en las ceremonias oficiales, en las fiestas cívicas o en las entradas solemnes de los príncipes y reyes en la ciudad. Esta jerarquía venía marcada por los mismos criterios utilizados para la representación política: la antigüedad del oficio, la consistencia numérica y económica de sus componentes, la mayor o menor dignidad de la actividad y su ubicación en el proceso productivo y en el mercado urbano. El orden procesional indicaba la estructura socio-profesional de la ciudad y sus rasgos político-administrativos,

\footnotetext{
${ }^{57}$ Lo mismo se observa en Castilla. J.A. SeSMA MuÑOZ, Cofradias, gremios y solidaridades, p. 25-26.

${ }^{58} \mathrm{H}$. ZAREMSKA, Les confréries religieuses à Cracovie entre la XIVème et le XVIème siècle, en Cofradías, gremios y solidaridades, pp.191-200.
} 
con una gran influencia de las circunstancias económicas y de la evolución cronológica de los oficios. El valor de las banderas, las insignias y los colores representativos de cada oficio era el resultado de una simbología paraheráldica que imitaba a la heráldica verdadera. En el estrato inferior se encontraban aquellos oficios que desfilaban primero. Eran los que tenían la actividad productiva relacionada con el abastecimiento y la alimentación (carnicers y flaquers). A su lado estaban las profesiones más bajas, es decir, las vinculadas con el cuero (aluders, assaonadors, corretgers y tapiners). No serían los oficios más humildes sino de los más controlados por la autoridad o más infamantes por el tipo de operaciones manuales que realizaban sus integrantes. En el estrato superior estarían los sastres, argenters, blanquers y por último los peraires, que contaban con el máximo prestigio social y eran el más numeroso y más potente económicamente hablando. Es decir que para unos el desfile significaba prestigio social y reconocimiento profesional, mientras que para otros era una imposición y una degradación jerárquica al asimilarlos al trabajo manual ${ }^{59}$.

Los desfiles urbanos y las fiestas ciudadanas contaban con la presencia de ediles, representantes de la realeza, autoridades eclesiásticas y miembros de las distintas cofradías. De esta manera expresaban la existencia de una jerarquía social concreta y asumida, reflejando a su vez una visión precisa de la vida terrenal y celestial ${ }^{60}$.

Otra forma de obtener prestigio social sería practicar la caridad cristiana mediante el socorro al necesitado, al pobre o al marginal, aquél que no ha sido capaz de integrase en el conglomerado urbano, ni por su pertenencia a un linaje nobiliario ni por su inclusión en una cofradía, sendos ejemplos de familia extensa frente a la escasa seguridad de la familia natural, a la ruptura que se producía en épocas de guerra o epidemia, a la inmigración causada por el éxodo rural o a los avatares económicos que podían conducir a la pobreza a ciudadanos asentados en el ámbito urbano.

Las ordenanzas de las cofradías valencianas mostraban este tipo de caridad en la pietança, aunque sólo un $18 \%$ de los reglamentos lo mencionan. El día del menjar, o comida de la cofradía, se mostraba la caridad confraternal invitando a los pobres a la comida, incluso en algunas ocasiones, después del menjar, se le daba al pobre una cantidad de dinero en metálico (unos pocos sueldos).

De esta manera se cumplía un doble objetivo: practicar la caridad cristiana con los más necesitados y aportar ante la sociedad urbana una imagen solidaria de amor hacia el prójimo ${ }^{6}$.

\footnotetext{
${ }^{59} \mathrm{P}$. IRADIEL, Corporaciones de oficio, pp.281-283.

${ }^{60} \mathrm{R}$. NARBONA VIZCAÍNO, Cortejos ceremoniales, funciones religiosas y simbolismos políticos en ls ciudades medievales, en Los cimientos del Estado en la Edad Media, p.234.

${ }^{61}$ "La valeur religieuse accordée à la figure du pauvre, vue à travers les courants de la vie apostolique et évangélique, ultérieurement ravivés par les ordres mendiants, notamment grâce à Francois d'Assise". C. VINCENT, Les confréries médiévales dans le Royaume de France. XIIII-XVe siècle, Paris, 1994, p.80
} 
Otras muestras de apariencia y prestigio que dieran una imagen de poder social a las cofradías se encuentran en elementos que podríamos etiquetar de suntuosidad y ostentación. ${ }^{62}$ Inicialmente, las cofradías se originaron a partir de una parroquia, y recibieron el nombre del santo o de la advocación mariana de dicha iglesia. Pero a medida que nos adentramos en su evolución comenzaron a desarrollarse hasta el punto de obtener bienes materiales propios: distintos tipos de joyas sin especificar, ornamentos de oro, plata y seda o de cualquier otro material valioso, ${ }^{63}$ ropas de lino y de seda para los cargos de la cofradía, mantos para los andadores, vestidos, calzas, tovalles, tovallons, etc. También se mencionaban esquelas para acompañar a los difuntos en sus entierros o en las procesiones religiosas, pendones reales con la señal de la cofradía para celebrar la fiesta del Corpus, fiestas solaces, honores reales y para fiestas con juglares. En la mayor parte de las cofradías se enumeraban paños de oro, plata, seda, lana, lino y de terciopelo, forrados o no, cuya finalidad era cubrir el cuerpo del difunto en su entierro. Como elementos propios de los sepelios también aparecían las literas o lechos -litsen un gran número de cofradías. En algunos casos, los cofrades difuntos eran trasladados a su tumba con el paño -drap- de la cofradía, que podía llevar bordado su señal o escudo.

El refinamiento, y su consiguiente valor simbólico, llegaba a ser extraordinario. En la cofradía de ligadors de bales (1404 y 1415) el drap se bordaba con una imagen de la virgen María, con la representación de la Navidad, estrellas y los tres Reyes Magos en plata y oro. ${ }^{64}$ Las ordenanzas también regulaban los tipos de paños que podía tener cada cofradía, ya fueran de oro, de seda o de terciopelo. ${ }^{65}$

Todos estos símbolos externos daban a entender una posición de poder económico y social. Lo mismo podría decirse del gran aparato lumínico, ya comentado anteriormente, en torno al uso de cirios, candelas y lanteas, que solían costearse con el dinero de las cuotas o con las penas impuestas a los cofrades.

\footnotetext{
62 “Dans la société médiévale l'apparence extérieure ne doit rien au hạsard. Elle obéit à un code au titre duquel chaque élément revêt une signification précise: ainsi, la queue du cheval de valet est nouée alors que flote librement celle du chevel de maître, les coiffures distinguent les degrés de dignité dans l'aristocratie, les couleurs du vêtement sont signes d'allégeance a telle famille ou tel parti politique". Ibidem p. 14

${ }^{63}$ Así sucedía en la cofradía de los ballesters de la ploma (1393). En las cofradías de Santa Trinidad y San Miguel de Xàtiva (1401) se enumeraban cruces, canelobres de oro, plata u otro metal. En las ordenanzas de San Antonio de Valencia (1393) se nombraban imágenes, coronas, pedits, pareges, perlas, correges y arneses. En al cofradía de ligadors de bales (1415) podían tener una imagen de la virgen con la representación del nacimiento de Jesucristo y la Adoración de los Reyes en plata y oro para llevarla sobre los cuerpos de los cofrades que murieran. En la cofradía de juponers $i$ vanovers (1418) y en la de ligadors de balas (1404) reglamentaban la posibilidad de hacer cruces de plata con ornamentos de piedras o perlas.

${ }^{64}$ Para los argenters (1392), los draps podían llevar la señal del oficio y la imagen de San Eloy. En la de juponers $i$ vanovers (1418) podían llevar la imagen de San Amador con algunas letras.

${ }^{65}$ Se hablaba en varias cofradías de paños de oro, de vellut, draps richs, paños de seda con imágenes de plata o de oro, de lana de lino o de cualquier otro tipo.
} 
Entre las posesiones más comunes estarían las cajas o cofres donde guardaban el dinero de las pecunias, los cirios, los privilegios, las cartas, las provisiones, los paños, el pendón del oficio, los libros de actas, las joyas, etcétera.

Pero las posesiones de tales hermandades no se reducían a bienes muebles, sino que también contaban con propiedades entre las que podemos incluir las capillas y casas confraternales o alberchs. Catorce cofradías -cerca del 19\%- solicitaron licencia para construir una capilla propia en la que venerar al patrón de la hermandad. De esas catorce, cinco incluían la petición de poseer un alberch donde reunirse, realizar las comidas, asistir a los entierros, etc. Incluso tres hermandades manifestaron su deseo de construir un cementerio propio para enterrar a los cofrades difuntos, lo cual sería una clara muestra de cohesión interna -los hermanos se entierran junto a los hermanos.

Estas posesiones estaban vinculadas directamente con la compra de censales, con lo que algunas cofradías alcanzaron un nivel de desarrollo que les conducía a participar en actividades crediticias, otorgando fadigas, recibiendo laudemios, firmando ventas, cambios y otras alienaciones de las posesiones confraternales.

\section{CONCLUSIONES \\ UN FENÓMENO EN PERMANENTE TRANSFORMACIÓN}

Desde la conquista de Valencia hasta el inicio de la modernidad, el movimiento confraternal valenciano mostró, por encima de cualquier otro aspecto, una permanente capacidad de transformación para adaptarse a las necesidades del periodo histórico estudiado. Pero el fenómeno asociativo en este territorio no fue únicamente pasivo y secundario, ni una respuesta a las actuaciones de otros agentes sociales. También fue un sujeto de los procesos en los que se ve envuelto, llegando a manifestar en algunos tramos una actitud exigente y combativa (la Unión o las Germanías son dos ejemplos palpables). Pero no hace falta recurrir a periodos de violencia para comprender sus intenciones de participar en el juego político, social y económico. Tales pretensiones debían de combinarse con los intereses de la Corona y de las autoridades municipales, con las fluctuaciones económicas y con las corrientes religiosas que trataban de ofrecer una respuesta a los desequilibrios de la vida urbana.

La aparición de los artesanos en las ciudades valencianas fue un paso fundamental y necesario para la consolidación económica del nuevo reino. Pero a su vez implicó la presencia de un grupo de ciudadanos que intentaron no pasar desapercibidos en el entramado urbano, que aspiraban a una expansión económica, y que este desarrollo a su vez tuviera su reflejo en las actuaciones políticas.

Las formas de participación en el control del municipio variaron dependiendo los intereses de los menestrales y de la acción de otras fuerzas 
incluidas en el ámbito ciudadano. Surgieron así diferentes modelos de organización, siendo el más elaborado y complejo el de las cofradías religiosas y de oficio, aunque no por ello resultó ser del todo coherente ni completó las necesidades de sus integrantes.

El proceso que siguieron algunas hermandades, incluyendo una reglamentación profesional mínima, acortó las distancias entre el oficio y la cofradía, pero en época medieval no se puede afirmar la existencia de una unión plena entre ambos.

Fecha de recepción del artículo: junio 2006.

Fecha de aceptación y versión final: agosto 2006. 